Article

\title{
Development of a Polyphenol Oxidase Biosensor from Jenipapo Fruit Extract (Genipa americana L.) and Determination of Phenolic Compounds in Textile Industrial Effluents
}

\author{
Rafael Souza Antunes ${ }^{1}$, Denes Ferraz ${ }^{2}{ }^{\circledR}$, Luane Ferreira Garcia ${ }^{1}$, Douglas Vieira Thomaz ${ }^{1}$,

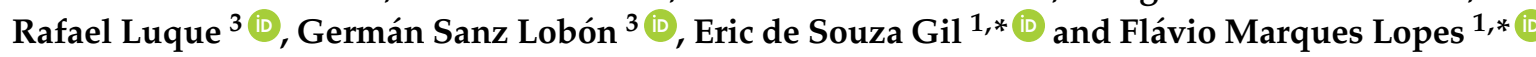 \\ 1 Faculdade de Farmácia, Universidade Federal do Goiás (UFG), Rua 221 Esquina com a 5 a Avenida s/n, \\ Setor Universitário, Goiânia-GO 74605-170, Brazil; rafael.antunes@panpharma.com.br or \\ rafael.s.antunes@hotmail.com (R.S.A.); luane.fg@hotmail.com (L.F.G.); douglasvthomaz@gmail.com (D.V.T.) \\ 2 Campus Henrique Santilo, BR-153, 3105, Universidade Estadual de Goiás, Fazenda Barreiro do Meio, \\ Anápolis-GO 75132-903, Brazil; denes.bio@hotmail.com \\ 3 Departamento de Química Orgánica, Universidad de Cordoba, 14014 Cordoba, Spain; \\ q62alsor@uco.es (R.L.); manger84@gmail.com (G.S.L.) \\ * Correspondence: ericsgil@ufg.br or ericsgil@gmail.com (E.d.S.G.); flaviomarques@ufg.br or \\ flaviomarques.ufg@gmail.com (F.M.L.); Tel.: +55-62-3209-6502 (E.d.S.G.); +55-62-3209-6044 (F.M.L.)
}

Received: 18 April 2018; Accepted: 11 May 2018; Published: 15 May 2018

\begin{abstract}
In this work, an innovative polyphenol oxidase biosensor was developed from Jenipapo (Genipa americana L.) fruit and used to assess phenolic compounds in industrial effluent samples obtained from a textile industry located in Jaraguá-GO, Brasil. The biosensor was prepared and optimized according to: the proportion of crude vegetal extract, $\mathrm{pH}$ and overall voltammetric parameters for differential pulse voltammetry. The calibration curve presented a linear interval from 10 to $310 \mu \mathrm{M}\left(\mathrm{r}^{2}=0.9982\right)$ and a limit of detection of $7 \mu \mathrm{M}$. Biosensor stability was evaluated throughout 15 days, and it exhibited $88.22 \%$ of the initial response. The amount of catechol standard recovered post analysis varied between $87.50 \%$ and $96.00 \%$. Moreover, the biosensor was able to detect phenolic compounds in a real sample, and the results were in accordance with standard spectrophotometric assays. Therefore, the innovatively-designed biosensor hereby proposed is a promising tool for phenolic compound detection and quantification when environmental contaminants are concerned.
\end{abstract}

Keywords: Genipa americana L.; polifenoloxidases; biosensor enzyme; phenolic compounds

\section{Introduction}

The contamination of soil and water by industrial residues presents a huge threat to the environment due to their large wastewater output. In this context, the activity from food, cellulose, pharmaceutical and textile industries releases a myriad of pollutants, the highly stable structures of which may further hinder environmental remediation [1].

Amongst these pollutants, phenolic compounds are notorious, hence their toxicity towards human and animal organisms. These molecules are nonetheless highly versatile concerning industrial use and are employed in polyamide production by textile industries [2], as well as a plethora of other applications [3].

Concerning the presence of phenolic compounds in waterbodies, these molecules are prone to bond themselves to chlorate, nitrate, methyl and other alkyl moieties, thus disturbing environment 
physicochemical proprieties such as $\mathrm{pH}$. Such disturbances, when associated with poor water treatment and human consumption, may henceforth lead to biological unbalances, which ultimately evolve to a variety of diseases $[4,5]$.

Phenolic compounds are considered impactful even at minute concentrations and have been listed by both the United States Environmental Protection Agency and the European Union as toxic pollutants of high concern $[2,6]$. Hence, the harmful effects of such compounds and the development of new assessment tools and remediation strategies are noteworthy.

The analysis of phenolic compounds in environmental samples is mostly achieved through liquid chromatography [7], high performance liquid chromatography $[8,9]$ and spectrophotometry $[1,3]$. However, such methods are expensive, unselective and mostly require the previous sample concentration. Therefore, the development of methods that allow fast, selective, low cost and practical contaminant assessment is of upmost importance [10].

Concerning phenolic pollutant analysis, biosensors are promising tools for their assessment, hence the enhanced selectivity of these devices, as well as fast analysis and low equipment cost. This kind of sensor is based on an enzymatic matrix, which provides process flexibility as the matrix organic portion can be altered according to the desired substrate under analysis [11-13].

Polyphenol oxidases (PPO) are a group of enzymes widely distributed in the plant kingdom and are responsible for phenol/quinone redox processes. These processes may be assessed by electrochemical methods such as voltammetry, which increases selectivity even further towards phenolic analytes. Furthermore, the ubiquitous distribution of PPO amongst plants allows different plant extracts to be used, and the accessibility provided by highly biodiverse biomes such as Cerrado further broadens the potential applications of biosensors [14-16].

Amongst potentially useful plants for biosensor development are Jenipapo (Genipa americana L.), a widely popular plant in Brazil whose folk use relies on its rich phenolic content. The presence of phenolic moieties among jenipapo secondary metabolites implies high PPO concentrations, which turns this fruit into an optimal source of crude vegetal extracts to be employed in biosensor production $[1,14]$

Therefore, the aim of this work was the development of a PPO-based biosensor from Jenipapo crude extract and employing it in the voltammetric assessment of phenolic compounds in industrial effluent samples obtained from a textile industry located in Jaraguá-Goiás.

\section{Materials and Methods}

\subsection{Reagents and Solutions}

All solutions and electrolytes were of analytical grade (Vetec Química Fina Ltd. (Rio de Janeiro, Brasil)). The water used was purified with a Millipore Milli-Q filter (Millipore S/A, (Molsheim, França)) and had an electrical conductivity of $\leq 0.1 \mu \mathrm{S} \mathrm{cm}{ }^{-1}$. The catechol standard was acquired from Sigma-Aldrich (St. Louis, MO, USA). All standard solutions were prepared by dilution of $1 \mathrm{mM}$ stock solutions, leading to a final concentration of $100 \mu \mathrm{M}$.

\subsection{Vegetal Material and Crude Extract Preparation}

Jenipapo fruits were collected from a single plant located in Anápolis-GO, Brasil, in January 2017 (geographic coordinates: $16^{\circ} 19^{\prime} 36^{\prime \prime} \mathrm{S} 48^{\circ} 57^{\prime} 10^{\prime \prime} \mathrm{W}$ ). Ten fruits were collected, rinsed with water and stored in polyethylene recipients at $4{ }^{\circ} \mathrm{C}$ until analysis.

Crude vegetal extract was prepared by milling $30 \mathrm{~g}$ of fruits for $2 \mathrm{~min}$ in a food processor (Britania, Brazil) and adding therein $100 \mathrm{~mL}$ phosphate buffer solution (PBS) $0.05 \mathrm{M}$ (pH 6.0). The solution was homogenized and filtrated on TNT fabric filter (nonwoven fabric), leading to a crude vegetal extract at $30 \%$ (Jenipapo enzymatic extract, JeEE) $0.01 \mathrm{M}$ (pH 6.0). All procedures were conducted at room temperature $\left(20 \pm 2{ }^{\circ} \mathrm{C}\right)$. 


\subsection{PPO Enzymatic Activity}

Spectrophotometry was used in order to evaluate PPO enzymatic activity. Therefore, $100 \mu \mathrm{L}$ of JeEE were added to $3 \mathrm{~mL}$ of catechol solution $0.07 \mathrm{M}$ in PBS media $0.05 \mathrm{M}$ (pH 6.0), and absorbance at $420 \mathrm{~nm}$ was evaluated after $10 \mathrm{~min}$ using a spectrophotometer (Q798U2VS, Quimis Aparelhos Científicos Ltd., São Paulo, Brasil) [17]. PPO activity was expressed in U/mg protein.

The determination of total proteins was conducted according to Bradford [18], using bovine serum albumin (BSA) as the standard solution. Thereafter, $100 \mu \mathrm{L}$ of JeEE and $5 \mathrm{~mL}$ Bradford reagent were added, and absorbance was evaluated at $595 \mathrm{~nm}$. All assays were conducted at room temperature $\left(20 \pm 2{ }^{\circ} \mathrm{C}\right)$.

\subsection{Biosensor Development}

Carbon paste was prepared using graphite powder and mineral oil from Sigma-Aldrich (St. Louis, MO, USA). Enzyme immobilization from JeEE was performed by physical adsorption on carbon paste. The enzymatic extract was added directly to the graphite powder and then homogenized. Thereafter, it was subjected to drying at $16 \pm 2{ }^{\circ} \mathrm{C}$ for a period of $30 \mathrm{~min}$. The mineral oil, which acts as a binder, was then added, and the whole blend was further homogenized (Table 1).

Table 1. PPO biosensor composition obtained from different Jenipapo crude extract proportions.

\begin{tabular}{cccc}
\hline Biosensor & Graphite Powder $(\mathbf{m g})$ & Vegetal Extract $(\mu \mathrm{L})$ & Mineral Oil $(\mathbf{m g})$ \\
\hline CP & 100 & - & 30 \\
CP-Jen50 & 100 & 50 & 30 \\
CP-Jen100 & 100 & 100 & 30 \\
CP-Jen200 & 100 & 200 & 30 \\
CP-Jen300 & 100 & 300 & 30 \\
\hline & $*$ CP $=$ carbon paste; Jen = Jenipapo.
\end{tabular}

The prepared carbon pastes were prepared to fill a cylindrical Teflon electrode $(\varnothing=1 \mathrm{~mm})$ as seen below (Figure 1).

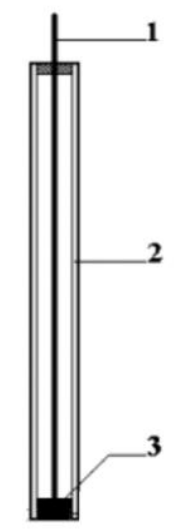

Figure 1. Cylindrical Teflon electrode (biosensor): (1) electric connection (copper wire); (2) Teflon lining; (3) carbon paste.

The amount of enzymatic extract to be used was optimized by studying the capacity of four different JeEE biosensor proportions to detect $0.07 \mathrm{M}$ catechol in PBS solution $0.05 \mathrm{M}(\mathrm{pH}=6.0)$, and the tested proportions were: $50 \mu \mathrm{L}$ (Carbon paste - Jenipapo $50 \mu \mathrm{L}, \mathrm{CP}-J e n 50), 100 \mu \mathrm{L}$ (CP-Jen100), $200 \mu \mathrm{L}$ (CP-Jen200) and $300 \mu \mathrm{L}$ (CP-Jen300), as shown in Table 1. The effect of $\mathrm{pH}$ in biosensor response towards catechol was evaluated for all systems using PBS $0.1 \mathrm{M}$, and $\mathrm{pH}$ was adjusted between 3.0 and 9.0 . 


\subsection{Electrochemical Analysis and Stability Assay}

Electrochemical analysis of oxidation products was determined by Differential Pulse Voltammetry (DPV) under the following experimental conditions: pulse amplitude $50 \mathrm{mV}$, pulse width $0.5 \mathrm{~s}$, scan rate $10 \mathrm{mV} \mathrm{s}^{-1}$. Between each assay, the biosensor was subjected to 10 scans from 0 to $1.0 \mathrm{~V}$ at $100 \mathrm{mV} \mathrm{s}^{-1}$ to stabilize the signal. The measurements were carried out in a $1.0-\mathrm{mL}$ electrochemical cell with a three-electrode system consisting of: a carbon paste electrode (CP, CP-Jen50, CP-Jen100, $\mathrm{CP}-J e n 200$ or $\mathrm{CP}-J e n 300)$, a platinum wire and the $\mathrm{Ag} / \mathrm{AgCl} / \mathrm{KCl} 3 \mathrm{M}$, representing the working electrode, the counter electrode and the reference electrode, respectively. The voltammograms were background subtracted and baseline corrected. All data were analyzed using Origin $8^{\circledR}$ software (OriginLab Corporation, Northampton, MA, USA).

The storage stability test (shelf) was performed for 15 days. Five carbon pastes were prepared at the same concentrations of JeEE (CP-Jen100) and stored at $4{ }^{\circ} \mathrm{C}$. After the following days, 1, 2, 5, 9 and 15, a sample (CP-Jen100) was recovered and allowed to warm at room temperature $\left(20 \pm 2{ }^{\circ} \mathrm{C}\right)$. The recovered carbon paste was used to fill the Teflon electrode (biosensor) and used to detect catechol in a $100 \mu \mathrm{M}$ catechol solution.

\subsection{Analytical Curve, Limit of Detection and Recovery Test}

An analytical curve was constructed based on DPV assays conducted in solutions of 10 to $310 \mu \mathrm{M}$. LoD was defined as the smallest catechol concentration able to be detected using the chosen electrode, which therefore led to a LoD below $10 \mu \mathrm{M}$.

In order to study precision and accuracy, a recovery test was undertaken. Therefore, 20, 30, 40, 50 and $60 \mu \mathrm{M}$ catechol solutions were added one at a time to a $100 \mu \mathrm{M}$ catechol solution. The recovery was calculated as displayed below [6]:

$$
\text { Recovery }(\%)=\left(\frac{\mathrm{C} 1-\mathrm{C} 2}{\mathrm{C} 3}\right) \times 100
$$

where $\mathrm{C} 1$ = final concentration; $\mathrm{C} 2=$ initial concentration; $\mathrm{C} 3=$ concentration of added solution.

\subsection{Industrial Effluent Sample}

The effluent sample was obtained from a textile industry specialized in jeans textile coloration located in Jaraguá-GO, Brasil (geographic coordinates $15^{\circ} 45^{\prime} 25^{\prime \prime} \mathrm{S} 49^{\circ} 20^{\prime} 04^{\prime \prime} \mathrm{W}$ ). The sample was collected before being subjected to any remediation procedure and stored in amber flasks until analysis. The samples were assessed using the proposed method to evaluate its viability towards real sample analysis.

\subsection{Statistical Analysis}

Statistical analysis was performed using the BioEstat program, Version 5.3. The statistic differences between groups were determined by the Student $t$-test. Statistical significance was considered as $p>0.05$ (95\%).

\section{Results and Discussion}

\subsection{PPO Activity and JeEE Total Proteins}

Preliminary studies concerning PPO enzymatic activity evidenced an activity of $593 \mathrm{U} / \mathrm{mg}$ proteins and an overall content of $1023 \mathrm{U} / \mathrm{mg}$ total proteins in $100 \mu \mathrm{L}$ crude vegetal extract, which was maintained throughout a storage time greater than two months at $0{ }^{\circ} \mathrm{C}$. The enzyme immobilization by adsorption was selected in this work due to its simplicity and easy execution [19,20].

The use of crude vegetal extracts on biosensors is a trend due to its analytical specificity, fast and reproducible analysis and excellent activity levels. Moreover, these enzymatic extracts have an 
extremely low cost, when compared to isolated enzymes. In this context, PPO-containing extracts are optimal for phenolic pollutant assessment [11,21,22].

Amongst PPOs, creolase and catecholase are responsible for the reversible conversion of $o$-diphenols to $o$-quinones. As these processes occur in potentials close to $0 \mathrm{~V}$, their detection is feasible by carbon paste electrodes whose matrix presents adsorbed PPO enzymes [23,24].

The biological function of PPOs is strictly related to their capacity to reversibly bond to oxygen through a copper $\left(\mathrm{Cu}^{2+}\right)$ active site, thus either oxidizing catechol to quinone or reducing quinone to catechol. These events are potential dependent and involve electron transfer, which is thereby detected in methods such as DPV $[25,26]$.

The oxidation of catechol can be assessed through an anodic scan, whereas the reduction of quinone to catechol is detected through a cathodic scan $[25,26]$. The aforementioned redox processes are represented below (Scheme 1).

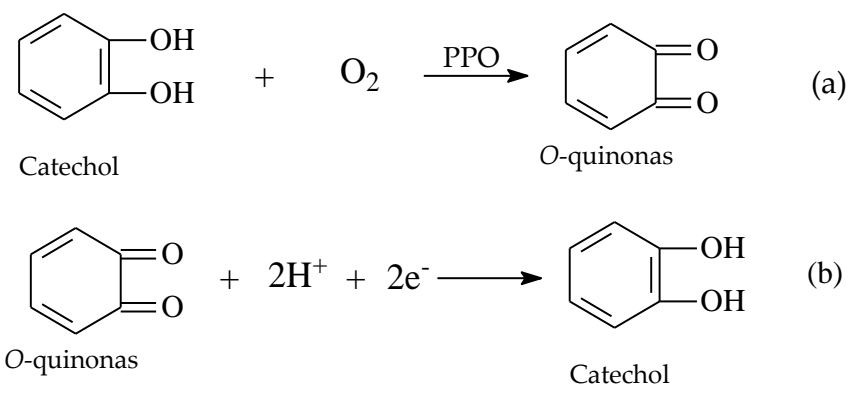

Scheme 1. (a) PPO-mediated oxidative catalysis of catechol; (b) o-quinone reduction to catechol.

\subsection{Biosensor Optimization}

In order to investigate the benefits of the designed electrode and optimize its response towards industrial effluents' analysis, a control test at different $\mathrm{pHs}$ was performed using an unmodified carbon paste electrode, as well as all different proportions of crude vegetal extract (Figure 2A-C).
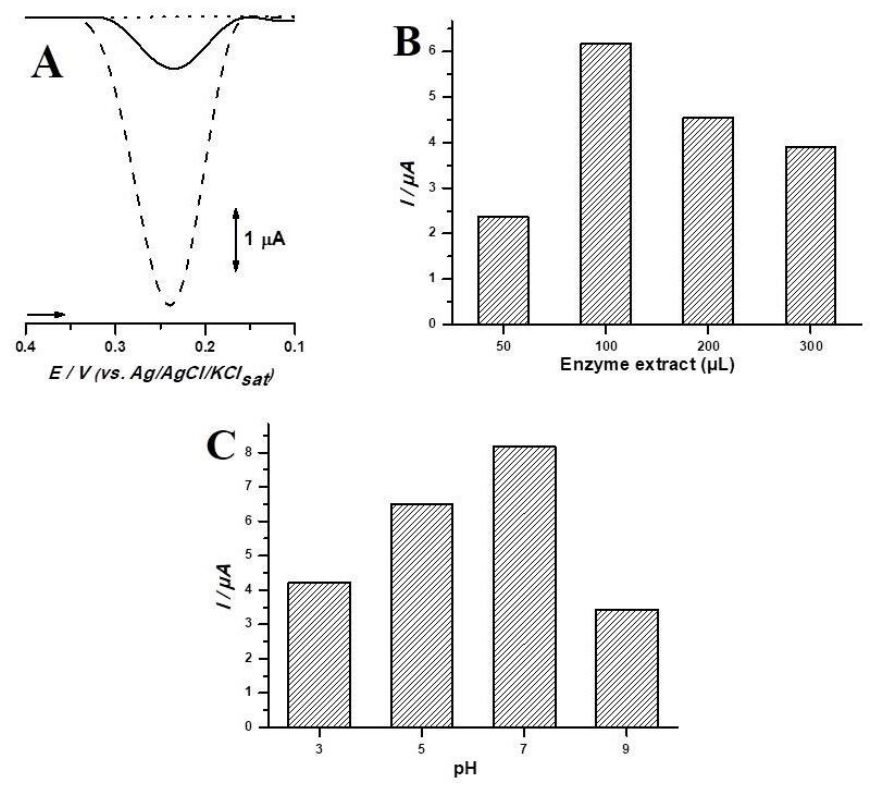

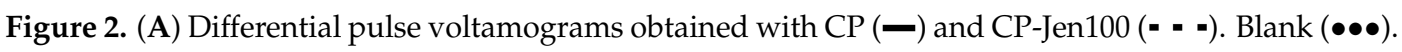
CP-Jen100 in PBS 0.1 M (pH 7.0). (B) Current peaks achieved through different crude vegetal extract proportions in the biosensor. (C) CP-Jen100 in PBS at different $\mathrm{pH}$ values. Analysis performed for a catechol solution of $0.07 \mathrm{mM}$ in PBS 0.05 M (pH 6.0). 
The performed assay evidenced the highest peak amplitude belonging to JeEE, whose enzymatic matrix promotes specificity, as well as enhanced selectivity and sensibility (Figure 2A). The best response was obtained with $100 \mu \mathrm{L} \mathrm{JeEE}$, which corresponds to an enzymatic activity of $593 \mathrm{U} / \mathrm{mg}$ proteins. It was clear that higher concentrations of crude vegetal extract lead to saturation, therefore hindering further detection and decreasing sensitivity (Figure 2B), and this event was previously reported in the literature [26]. The best $\mathrm{pH}$ was of 7.0 (Figure 2C). This value is in consonance with the literature, whose reports state better PPO activity at neutral $\mathrm{pH}$ values [14,15].

\subsection{Analytical Curve for Catechol}

The linearity of the proposed method was evidenced through an analytical curve. Results indicated that the method response was proportional to analyte concentration increment (Figure 3). Linearity was proven from catechol concentrations of 10 to $310 \mu \mathrm{M}\left(\mathrm{r}^{2}=0.9982\right)$. Peak values varied from -0.368 to $-12.7 \mu \mathrm{A}$, and curve equation corresponded to $I / \mu A=-0.07958-0.03873$ (catechol $\mu \mathrm{M})$. Therefore, LoD was also determined, being $7 \mu \mathrm{M}$ for CP-Jen100.

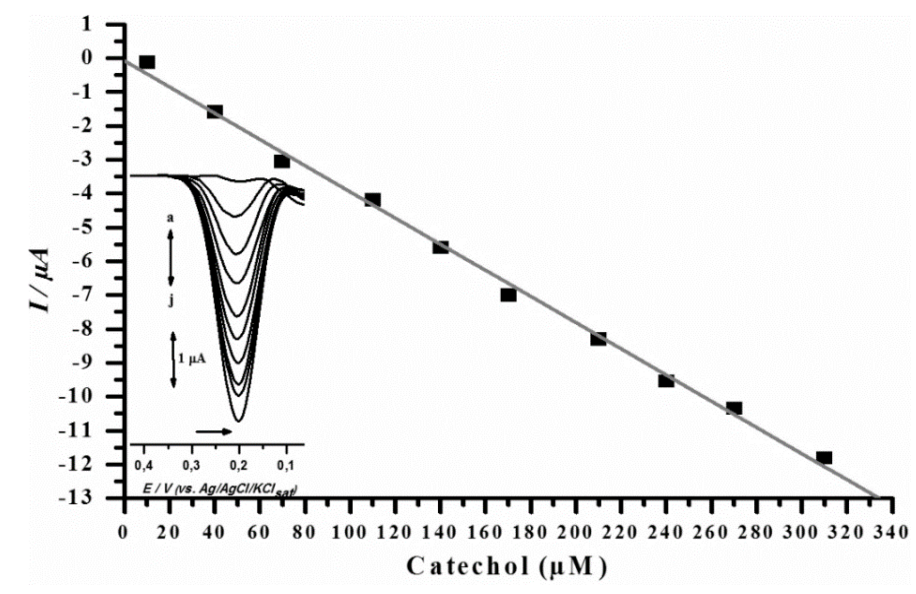

Figure 3. Analytical curve and DPVs obtained through CP-Jen100 at different catechol concentrations in PBS 0.1 M (pH 7.0).

\subsection{Stability Assay}

The CP-Jen100 stability was assessed during 15 days. At the end of the 15 th day, $88.22 \%$ of the initial response was maintained towards the detection of catechol in a $100 \mu \mathrm{M}$ solution (Figure 4). Therefore, enzyme immobilization through adsorption was efficient enough to resist lixiviation.

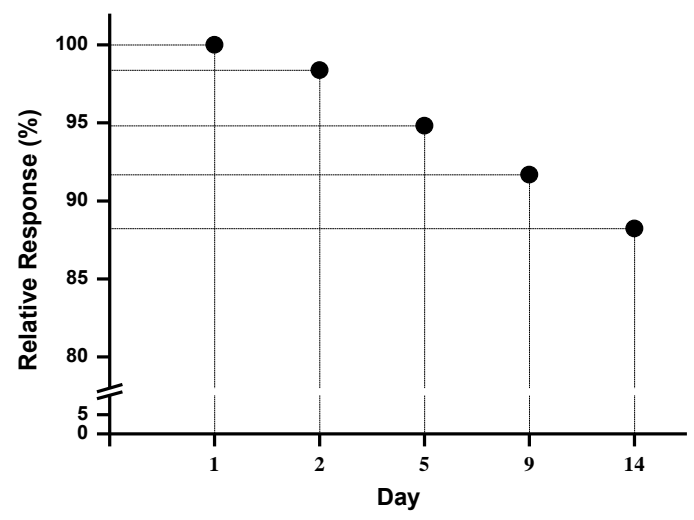

Figure 4. Relative response obtained according to the CP-Jen100 storage time. Analysis performed at $0.07 \mathrm{mM}$ catechol solution in PBS 0.1 M (pH 7.0). 


\subsection{Recovery Assay}

The recovery assay was conducted in order to assess method precision and accuracy. Results indicated an accuracy of 87.50 to $96.00 \%$ (Table 2).

Table 2. Recovery assay results for catechol standard using the jenipapo PPO biosensor.

\begin{tabular}{|c|c|c|c|c|}
\hline Catechol $(\mu \mathrm{M})^{1}$ & $\begin{array}{l}\text { Catechol Added } \\
(\mu \mathrm{M})^{2}\end{array}$ & $\begin{array}{l}\text { Catechol Expected } \\
\qquad(\mu \mathrm{M})^{3}\end{array}$ & $\begin{array}{l}\text { Catechol Recovery } \\
\qquad(\mu \mathrm{M})^{4}\end{array}$ & $\begin{array}{l}\text { Catechol Recovery } \\
(\%)^{5}\end{array}$ \\
\hline 100 & 20 & 120 & $119 \pm 0.93$ & 95.00 \\
\hline 100 & 30 & 130 & $127 \pm 1.03$ & 90.00 \\
\hline 100 & 40 & 140 & $135 \pm 0.77$ & 87.50 \\
\hline 100 & 50 & 150 & $148 \pm 0.37$ & 96.00 \\
\hline 100 & 60 & 160 & $156 \pm 1.22$ & 93.33 \\
\hline
\end{tabular}

The recovery indexes were between $70 \%$ and $120 \%$, which is in accordance with the literature concerning the analysis of textile industry phenolic contaminants [6], therefore indicating that the method was precise and accurate.

\subsection{Analysis of Phenolic Contaminants in the Industrial Sample}

Concerning phenolic contaminant analysis, tests are usually performed through spectrophotometry. Therefore, a comparison between a standard test and the hereby proposed test was needed in order to further prove its usefulness towards real sample assessment [6].

The obtained values for each assay, as well as the statistical significance are displayed below (Table 3).

Table 3. Phenolic compounds detected in the industrial effluent sample by CP-Jen100 and spectrophotometry.

\begin{tabular}{ccc}
\hline Method & Total Phenols $(\boldsymbol{\mu M})(\mathbf{n}=4)$ & Student $t$ Test \\
\hline Spectrophotometry & $238.90 \pm 0.99$ & 0.15 \\
DPV using Jen100 biosensor & $240.46 \pm 0.84$ & \\
\hline
\end{tabular}

The results show that no statistical difference can be attributed to the experimental values. Therefore, the method is reliable and reproductive. Moreover, a standard deviation of 0.84 was found for the biosensor, which is below that for spectrophotometry. Thus, the biosensor is more reliable than spectrophotometry analysis.

\section{Conclusions}

The designed biosensor was successfully employed to detect phenolic contaminants in a real sample from a textile industry, and no significant statistical difference between the described method and the standard spectrophotometric one was found. The new method presents nonetheless excellent recovery levels (70-120\%). Furthermore, the biosensor was reliable, accurate, precise, robust and conformed to all analytical standards, being a reproducible tool to assess phenolic contaminants in industrial effluents.

Author Contributions: R.S.A., F.M.L., E.d.S.G. and L.F.G. conceived of and designed the experiments. R.S.A., D.F. and L.F.G. performed the experiments. R.L., G.S.L. and E.d.S.G. analyzed the data. E.d.S.G. and F.M.L. contributed reagents / materials/analysis tools. R.S.A., D.V.T. and E.d.S.G. wrote the paper.

Funding: This research was funded by Conselho Nacional de Desenvolvimento Científico e Tecnológico-CNPq.

Conflicts of Interest: The authors declare no conflict of interest. 


\section{References}

1. Lavilla, I.; Gil, S.; Costas, M.; Bendicho, C. Dispersive liquid-liquid microextraction combined with microvolume spectrophotometry to turn green the 5530 APHA standard method for determining phenols in water and wastewater. Talanta 2012, 98, 197-202. [CrossRef] [PubMed]

2. Zeng, Z.; Tian, L.; Li, Z.; Jia, L.; Zhang, X.; Xia, M.; Hu, Y. Whole-cell method for phenol detection based on the color reaction of phenol with 4-aminoantipyrine catalyzed by CotA laccase on endospore surfaces. Biosens. Bioelectron. 2015, 69, 162-166. [CrossRef] [PubMed]

3. Nassiri, M.; Zahedi, M.M.; Pourmortazavi, S.M.; Yousefzade, M. Optimization of dispersive liquid-liquid microextraction for preconcentration and spectrophotometric determination of phenols in Chabahar Bay seawater after derivatization with 4-aminoantipyridine. Mar. Pollut. Bull. 2014, 86, 512-517. [CrossRef] [PubMed]

4. Apetrei, I.M.; Apetrei, C. The biocomposite screen-printed biosensor based on immobilization of tyrosinase onto the carboxyl functionalised carbon nanotube for assaying tyramine in fish products. J. Food Eng. 2015, 149, 1-8. [CrossRef]

5. Sumana, G.; Das, M.; Srivasta, S.; Malhotra, B.D. A novel urea biosensor based on zirconia. Thin Solid Films 2010, 519, 1187-1191. [CrossRef]

6. BRASIL, Conselho Nacional de Meio Ambiente (CONAMA). Resolução RDC n 397, 7 de Abril de 2008. Available online: http:/ / www.mma.gov.br/port/conama/legiabre.cfm?codlegi=563 (accessed on 14 May 2018).

7. Asan, A.; Isildak, I. Determination of major phenolic compounds in water by reversed-phase liquid chromatography after pre-column derivatization with benzoyl chloride. J. Chromatogr. A 2003, 988, 145-149. [CrossRef]

8. Ou, J.; Hu, L.; Hu, L.; Li, X.; Zou, H. Determining of phenolic compounds in river waterwith on-line coupling bisphenol A imprinted monolithic pre-column with high performance liquid chromatography. Talanta 2006, 69, 1001-1006. [CrossRef] [PubMed]

9. Feng, Q.; Zhao, L.; Lin, J.M. Molecularly imprinted polymer as micro-solid phase extraction combined with high performance liquid chromatography to determine phenolic compounds in environmental water samples. Anal. Chim. Acta 2009, 650, 70-76. [CrossRef] [PubMed]

10. Pundir, S.; Chauhan, N.; Narang, J.; Pundir, C.S. Amperometric choline biosensor based on multiwalled carbon nanotubes/zirconium oxide nanoparticles electrodeposited on glassy carbon electrode. Anal. Biochem. 2012, 427, 26-32. [CrossRef] [PubMed]

11. Antunes, R.S.; Lopes, F.M.; Brito, A.O.; Garcia, L.F.; Sousa, D.F.; Gil, E.S. Enzimas vegetais: extração e aplicações biotecnológicas. Infarma 2017, 29, 181-198. [CrossRef]

12. Apetrei, C.; Rodriguez-Mendez, M.L.; De Saja, J.A. Amperometrictyrosinase based biosensor using na electropolymerized phosphate-doped polypyrrole film as an immobilization support. Application for detection of phenolic compounds. Electrochim. Acta 2011, 56, 8919-8925. [CrossRef]

13. Lu, L.; Zhang, L.; Zhang, X.; Huan, S.; Shen, G.; Yu, R. A novel tyrosinase biosensor based on hydroxyapatite-chitosan nanocomposite for the detection of phenolic compounds. Anal. Chim. Acta 2010, 665, 146-151. [CrossRef] [PubMed]

14. Campos, L.F.C.; Peixoto, J.V.M.; Oliveira, R.M.; Seleguini, A.; Nascimento, A.R. Propriedades físico-químicas de frutos de jurubeba de três regiões do Cerrado. Rev. Agric. Neotrop. 2015, 2, 48-54.

15. Calas-Blanchard, C.; Istamboulié, G.; Bontoux, M.; Plantard, G.; Goetz, V.; Noguer, T. Biosensor-based real-time mornitoring of paracetamol photocatalytic degradation. Chemosphere 2015, 9, 124-131. [CrossRef] [PubMed]

16. Rodrigues, N.F.M.; Neto, S.Y.; Luz, R.C.S.; Damos, F.S.; Yamanaka, H. Ultrasensitive Determination of Malathion Using Acetylcholinesterase Immobilized on Chitosan-Functionalized Magnetic Iron Nanoparticles. Biosensors 2018, 8, 16. [CrossRef] [PubMed]

17. Terefe, N.S.; Delon, A.; Buckow, R.; Versteeg, C. Blueberry polyphenol oxidase: Characterization and the kinetics of thermal and high pressure activation and inactivation. Food Chem. 2015, 188, 193-200. [CrossRef] [PubMed]

18. Bradford, M. A rapid and sensitive method for the quantitation of microgram quantities of protein utilizing the principle of protein-dye binding. Anal. Biochem. 1976, 72, 248-254. [CrossRef] 
19. Garcia, L.F.; Benjamin, S.R.; Antunes, R.S.; Lopes, F.M.; Somerset, V.S.; Gil, E.S. Solanum melongena polyphenol oxidase biosensor for the electrochemical analysis of paracetamol. Prep. Biochem. Biotechnol. 2016, 46, 850-855. [CrossRef] [PubMed]

20. Nanduri, V.; Sorokulova, I.B.; Samoylov, A.M.; Simonian, A.L.; Petrenko, V.A.; Vodyanoy, V. Phage as a molecular recognition elemento in biosensors immobilized by physical adsorption. Biosens. Bioelectron. 2007, 22, 986-992. [CrossRef] [PubMed]

21. Ganesh, H.V.S.; Noroozifar, M.; Kerman, K. Epigallocatechin Gallate-Modified Graphite Paste Electrode for Simultaneous Detection of Redox-Active Biomolecules. Sensors 2018, 18, 23. [CrossRef] [PubMed]

22. Narang, J. A nylon membrane based amperometric biosensor for polyphenol determination. J. Mol. Catal. B Enzym. 2011, 72, 276-281. [CrossRef]

23. Mishra, B.B.; Gautam, S.; Sharma, A. Purification and characterization of polyphenol oxidase (PPO) from eggplant. Food Chem. 2012, 34, 1855-1861. [CrossRef] [PubMed]

24. Polesel, D.N.; Sinhorini, A.L.C.; Perone, C.A.S. Caracterização cinética da enzima catecolase (Polifenoloxidase) em extratos brutos da polpa e da casca de berinjela (Solanum melongena L.). J. Health Sci. Inst. 2010, 28, 175-180.

25. Ahmad, N.M.; Abdullah, J.; Yusof, N.A.; Rashid, A.H.A.; Rahman, S.A.; Hasan, M.R. Amperometric Biosensor Based on Zirconium Oxide/Polyethylene Glycol/Tyrosinase Composite Film for the Detection of Phenolic Compounds. Biosensors 2016, 6, 31. [CrossRef] [PubMed]

26. Antunes, R.S.; Garcia, L.F.; Somerset, V.S.; Gil, E.S.; Lopes, F.M. The Use of a Polyphenoloxidase Biosensor Obtained from the Fruit of Jurubeba (Solanum paniculatum L.) in the Determination of Paracetamol and Other Phenolic Drugs. Biosensors 2018, 8, 36. [CrossRef] [PubMed]

(C) 2018 by the authors. Licensee MDPI, Basel, Switzerland. This article is an open access article distributed under the terms and conditions of the Creative Commons Attribution (CC BY) license (http://creativecommons.org/licenses/by/4.0/). 